\title{
Simulasi CFD pada Kapal Planing Hull
}

\author{
Samuel $^{\left.l^{*}\right)}$, Andi Trimulyono, Ari Wibawa Budi Santosa \\ ${ }^{1)}$ Departmen Teknik Perkapalan, Fakultas Teknik, Universitas Diponegoro, Semarang \\ Jl. Prof. Soedarto, SH, Kampus Undip Tembalang, Semarang, Indonesia 50275
}

\author{
diajukan pada:07/11/19 direvisi pada : 12/11/19 diterima pada $: 13 / 11 / 19$
}

\begin{abstract}
Abstrak
Akurasi dalam memprediksi hambatan kapal adalah salah satu aspek penting dalam mendesain lambung kapal. Secara umum, hambatan kapal dengan type planing lebih rumit daripada type displacement. Planing hull memiliki karakteristik unik seperti trim, heave, hard-chine, Froude number tinggi dan dead-rise angle. Gaya hidrodinamik pada planing hull lebih dominan daripada gaya hidrostatik. Analisis numerik menggunakan Finite Volume Method (FVM) dipilih untuk menyelesaikan masalah hidrodinamik. Dalam penelitian ini, persamaan (RANS Reynolds-Averaged Navier-Stokes) digunakan untuk menggambarkan model turbulensi dengan $k$ - $\varepsilon$. Secara umum, pemodelan Volume of Fluid (VOF) menggunakan aliran multiphase Euler yang diasumsikan air dan udara sebagai phase. Tujuan dari penelitian ini adalah untuk memperkenalkan perhitungan kapal type planing hull untuk memprediksi hambatan kapal dan seakeeping. Studi validasi ini dilakukan dengan menggunakan eksperimen Fridsma hullform. Hasil pada penelitian ini menunjukkan bahwa simulasi numerik pada jenis planing hull dapat diprediksi dengan akurasi yang cukup baik.
\end{abstract}

Copyright @ 2019, KAPAL, 1829-8370 (p), 2301-9069(e)

Kata Kunci : Planing hull, CFD, Finite Volume Method, Volume of Fluid, RANS

\section{PENDAHULAN}

Penelitian yang yang dilakukan oleh Fridsma telah menginspirasi para peneliti untuk mempelajari prediksi hambatan, heave dan pitch pada type kapal planing hull. Ada beberapa penelitian yang berkaitan dengan validasi kapal planing hull. Studi eksperimental planing hull dilakukan secara bertahap pada gelombang regular [1] dan gelombang irregular [2]. Secara khusus Fridsma berkontribusi menggunakan lambung prisma menggunakan non-dimensional unit $\left(\mathrm{v} / \mathrm{L}^{0.5}\right)$ deadrise yang berbeda. Penelitian lainnya, Daniel Savitsky memberikan kontribusi dengan melakukan pengujian experimental dengan menggunakan pendekatan formula empirical dengan mendefinisikan gaya angkat, hambatan, permukaan basah, tekanan dan porposing [3].

\footnotetext{
*) Penulis Korespondensi :

Email : undip_samuel@yahoo.com
}

Menurut beberapa literatur yang dilakukan oleh Yousefi pada tahun 2013, simulasi numerik dapat dilakukan untuk memprediksi fenomena aliran disekitar lambung kapal planing hull [4]. Beberapa penelitian menggunakan software Ansys-FLUENT [5], [6], Ansys-CFX [7], CFDship-Iowa [8], COMET [9], [10], ALE-VMS [11] dan Star-CCM+ [12]-[14]. Metode yang paling sering digunakan untuk memprediksi hambatan dan gerakan planing hull adalah FVM (Finite Volume Method), FEM (Finite Element Method) dan FDM (Finite Difference Method) serta analitik-experiment. Menurut data penelitian diatas, metode yang paling sering digunakan untuk memprediksi hambatan, trim dan heave adalah $F V M$.

Pada saat beroperasional, planing hull memiliki konsentrasi pada hambatan, trim dan heave; sehingga penelitian ini bertujuan untuk memprediksi hambatan, trim dan heave dengan mendefinisikan geometri, titik berat, titik apung dan moment inersia kapal. Manfaat dari studi ini 
adalah untuk memberikan informasi benchmark yang akurat pada penelitian selanjutnya yang lebih kompleks. Simulasi ini dilakukan menggunakan paket software komersial yang dikembangkan oleh star-CCM+.

\section{METODE}

\subsection{Objek Penelitian}

Objek penelitian ini adalah kapal Fridsma hull form untuk memprediksi hambatan, trim dan heave. Data kapal yang digunakan adalah kapal dalam skala model eksperimen yang sudah dilakukan pengujian towing tank pada table 1 .

Table 1. Data Fridsma hull form [1]

\begin{tabular}{lllll}
\hline Dimension & A & B & C & D \\
\hline L (m) & 1.143 & 1.143 & 1.143 & 1.143 \\
B (m) & 0.229 & 0.229 & 0.229 & 0.229 \\
L/B & 5 & 5 & 5 & 5 \\
$\beta$ & 20 & 20 & 20 & 20 \\
LCG (m) & 59.00 & 62.00 & 61.50 & 67.50 \\
C.G from & & & & \\
baseline & 0.0672 & 0.0672 & 0.0672 & 0.0672 \\
$(\mathrm{~m})$ & & & & \\
k (\%) & 25.1 & 25.5 & 25.3 & 26.5 \\
v (m/s) & 4 & 6 & 2 & 2 \\
\hline
\end{tabular}

\subsection{Perlakuan Pada Objek}

Persamaan yang digunakan untuk mendefinisikan garis pada gambar kapal dapat dilihat pada gambar 1 .

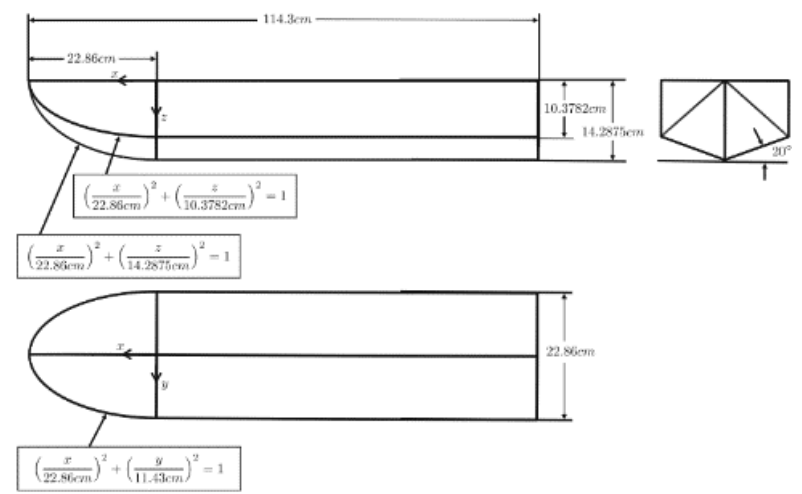

Gambar 1. Persamaan garis pada Fridsma hull form

Persamaan garis dimodelkan menggunakan NURBS untuk mendapatkan garis, surface dan volume kapal. NURBS (Non-Uniform, Rational B-spline Surface) adalah model matematika dengan menggunakan computer untuk merepresentasikan bentuk garis dan surface.
Pemodelan kapal dilakukan dengan menggunakan polysurface untuk mendapatkan bentuk kapal yang solid atau tertutup (gambar 2).

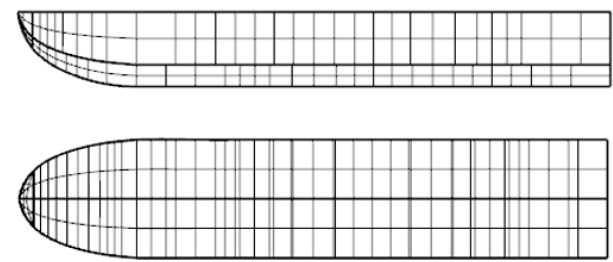

Gambar 2. Pemodelan 3D Fridsma hull form

\subsection{Metode Penelitian}

Tujuan penting dari setiap program CFD adalah untuk menyelesaikan persamaan dengan menggunakan pendekatan boundary dan initial conditions. Persamaan Reynolds-averaged Navier-Stokes (RANS) mempresentasikan hukum konservasi massa dan momentum. Setiap cell diasumsikan sebagai volum fraksi yang memiliki nilai 1 dan 0 . Fungsi fluida air dan udara tergantung dari properti volum fraksi. Permukaan air laut diasumsikan F, sebagai hukum konservasi:

$$
\frac{\delta F}{\delta t}+\frac{\delta u F}{\delta x}+\frac{\delta v F}{\delta y}+\frac{\delta w F}{\delta z}=0
$$

Persamaan RANS dikembangkan berdasarkan konsep bahwa kecepatan dan panjang kapal cukup untuk menggambarkan efek turbulensi di sekitar lambung. Dalam perhitungan, model turbulensi $\mathrm{k}-\varepsilon$ yang berfungsi sebagai dinding yang digunakan untuk menggambarkan efek turbulensi pada aliran [15].

ITTC membantu perhitungan CFD sebagai pedoman praktis. Informasi jumlah minimum cell yang direkomendasikan per amplitudo gelombang dan panjang gelombang memberikan akurasi dalam memprediksi hambatan [16]. ITTC merekomendasikan cell per tinggi gelombang $1 / 40 \mathrm{~s} / \mathrm{d} 1 / 20$.

Untuk menentukan banyaknya cell yang digunakan pada dinding kapal digunakan nilai $\mathrm{y}+$. Nilai $y+$ juga dibahas untuk mengurangi ketidakuratan perhitungan. Nilai y+ direkomendasikan pada Star CCM+ dan ITTC yaitu:

$$
\frac{y}{L}=\frac{y^{+}}{R_{e} \sqrt{\frac{C_{f}}{2}}}
$$


Lotfi melakukan penelitian untuk mendapatkan hasil yang akurat menggunakan nilai y+ antara 50 - 150 [7]. Untuk menentukan time-step pada perhitungan CFD tergantung pada kecepatan kapal dan pengambilan data pada saat perhitungan. Semakin cepat kapal maka semakin kecil time-step yang digunakan. Berdasarkan perhitungan yang direkomendasikan oleh ITTC, nilai time-step yaitu:

$$
\Delta t I T T C=0.005 \backsim 0.01 \frac{L}{U}
$$

Pada penelitian ini nilai time-step yang digunakan terletak diantara 0.008 , sesuai dengan gambar 3 .

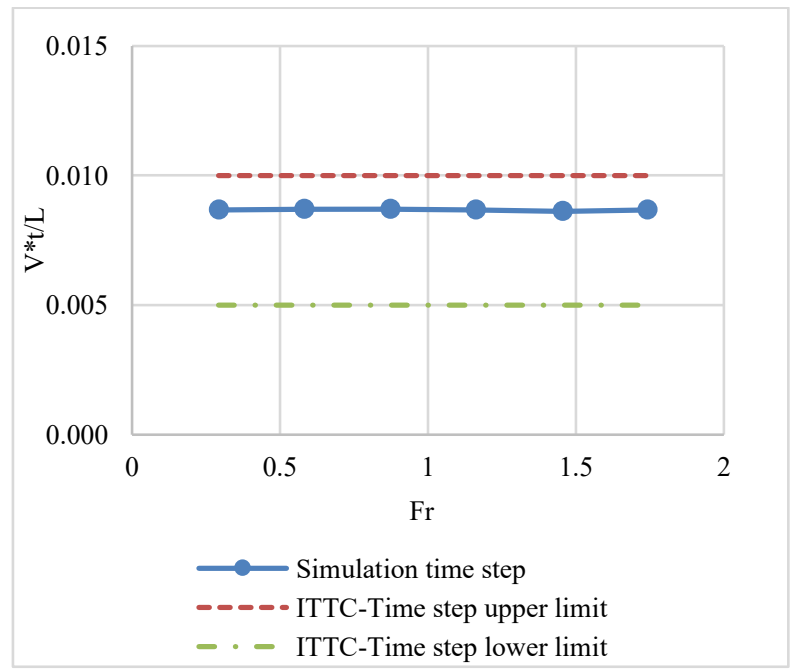

Gambar 3. Penggunaan time-step CFD

Ilustrasi domain yang digunakan untuk merepresentasikan towing tank menggunakan koordinat kartesian pada gambar 4. Untuk mengurangi waktu komputasi digunakan setengah badan kapal. Jarak dinding depan terhadap haluan depan kapal 1 LOA, jarak dinding belakang terhadap buritan kapal 2.5 LOA, jarak dinding samiping terhadap midship kapal 1.5 LOA dan jarak dinding bawah terhadap dinding atas 3 LOA seperti yang ditunjukan pada gambar 4 .

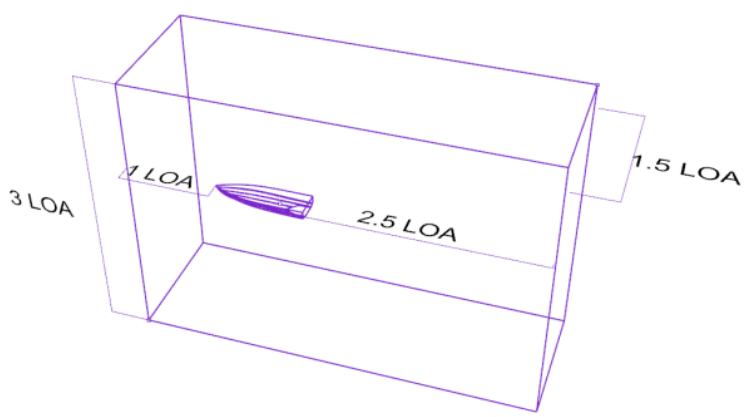

Gambar 4. Ilustrasi towing tank pada simulasi CFD
Kerapatan mesh yang digunakan pada penelitian ini fokus pada permukaan air. Kerapatan mesh secara lokal dilakukan pada koordinat $\mathrm{x}, \mathrm{y}, \mathrm{z}$ dengan menggunakan isotropic atau anisotropic. Semakin rapat penggunaan mesh akan menambah waktu perhitungan dan begitupula sebaliknya. Sehingga konsentrasi mesh fokus pada bagian yang dianggap penting. Lokasi kerapatan mesh dibagi menjadi beberapa bagian yang diberikan pada tabel 2 dan gambar 5 .

Pada simulasi CFD gerak kapal dibatasi dengan membebaskan gerakan heave dan pitch, sementara gerakan kapal yang lain tidak digunakan. Asumsi ini digunakan untuk memprediksi trim dan gerakan naik turun kapal.

Tabel 2. Kerapatan mesh

\begin{tabular}{llc}
\hline Bagian & Nama & Dimensi \\
\hline 1 & Far field & $0.060 \mathrm{~L}$ \\
2 & Block 1 & $0.007 \mathrm{~L}$ \\
3 & Block 2 & $0.030 \mathrm{~L}$ \\
4 & Free surface & $0.002 \mathrm{~L}$ \\
5 & Hull & $0.006 \mathrm{~L}$ \\
\hline
\end{tabular}

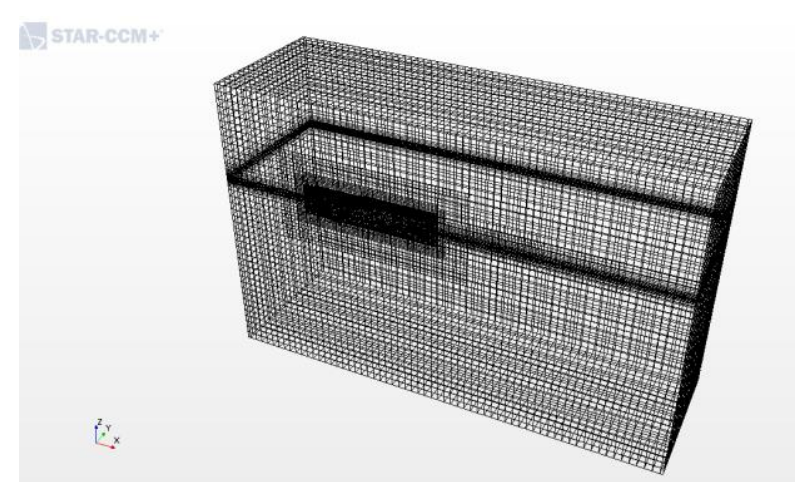

Gambar 5. Ilustrasi konfigurasi kerapatan mesh

\section{HASIL DAN PEMBAHASAN}

Alasan utama untuk memilih bentuk lambung yang digunakan oleh Fridsma adalah bentuk geometri yang sangat sederhana dan data eksperimen yang sangat akurat. Simulasi eksperimen pada air tenang dan gelombang menggambarkan efek deadrise, trim, loading, kecepatan, rasio panjang-lebar kapal, dan added resistance.

Penelitian pada kondisi air tenang digunakan untuk menentukan kecepatan pada kondisi gelombang. Kecepatan yang dipilih pada kondisi gelombang adalah $2 \mathrm{~m} / \mathrm{s}$ dan $6 \mathrm{~m} / \mathrm{s}$, sesuai dengan table 1. Pada gambar 6, menunjukan simulasi CFD dan eksperimen pada kondisi air tenang. Total hambatan kapal menunjukan kemiripan pada non-dimensional unit Froude Number (Fr) 
dan Rasio hambatan dan displasemen (R/ $\triangle$ ). Fr adalah fungsi dari kecepatan kapal dan panjang kapal. R/ $\triangle$ adalah fungsi hambatan kapal dan displacement kapal.

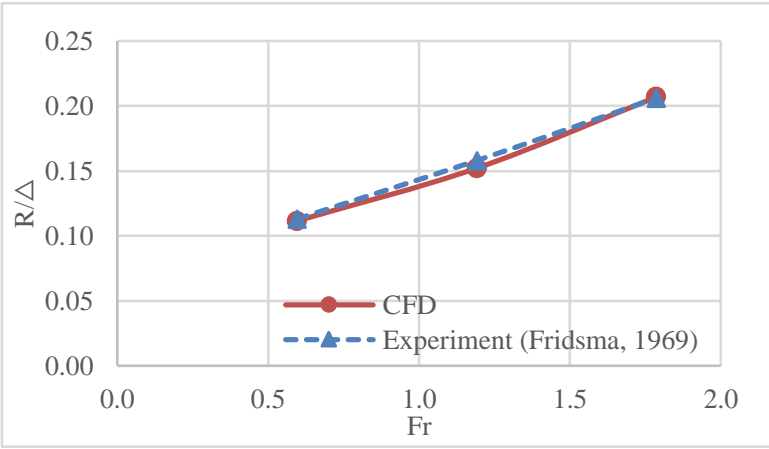

Gambar 6. Perbandingan CFD dan eksperimen pada kondisi air tenang

Perbedaan pressure pada kondisi air tenang ditunjukan pada gambar 7. Pada gambar tersebut menunjukan adanya perbedaan gaya yang terjadi karena tekanan air. Kondisi ini menunjukan bahwa gaya terbesar terjadi pada titik stagnasi kapal.

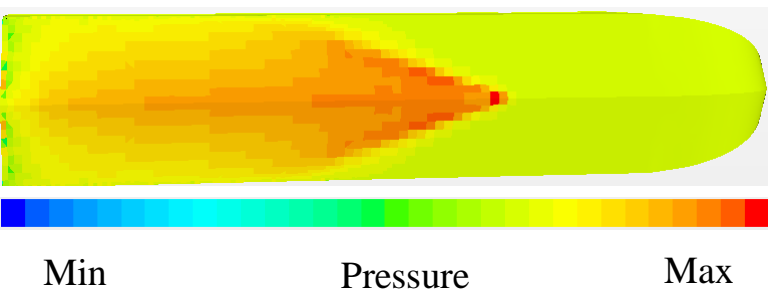

Gambar 7. Perbedaan pressure pada saat simulasi CFD

Berdasarkan gambar 8, menunjukan perbandingan hambatan total, pitch dan heave dengan menggunakan CFD dan eksperimen. Pada kondisi kecepatan kapal $\mathrm{Fr}=1.78$ dengan tinggi gelombang $0.025 \mathrm{~m}$ perbandingan pitch dan heave menunjukan hasil perhitungan CFD cukup baik, akan tetapi pada perhitungan hambatan terjadi perbedaan. Perbedaan ini terjadi karena ketidakmampuan CFD untuk mendefinisikan volum fraksi pada kecepatan kapal yang sangat tinggi.

Memodifikasi kerapatan mesh dan time-step dilakukan untuk mengurangi nilai eror, tetapi tidak dapat diselesaikan dengan sempurna. Kejadian ini juga pernah dibahas oleh Federici, bahwa ada pengurangan total hambatan sampai dengan 30\% [17]. Ahmed Gultekin Avci juga pernah melakukan hal yang sama, untuk menyelesaikan permasalahan ini, maka untuk menyelesaikan permasalahan ini digunakan penambahan sebanyak $15 \%$ dari toal hambatan kapal [14].

Non-dimensional unit yang digunakan pada kondisi gelombang adalah $2 \theta_{\mathrm{A}} /(2 \pi H / \lambda), 2 \mathrm{z}_{\mathrm{A}} / \mathrm{H}$, dan $\lambda /$ L. $2 \theta_{\mathrm{A}} /(2 \pi H / \lambda)$ adalah fungsi dari Amplitudo pitch motion $\left(\theta_{\mathrm{A}}\right)$, tinggi gelombang $(\mathrm{H})$, Panjang gelombang $(\lambda) ; 2 \mathrm{z}_{\mathrm{A}} / \mathrm{H}$ adalah fungsi dari Amplitudo heave motion $\left(\mathrm{z}_{\mathrm{A}}\right) . \lambda / \mathrm{L}$ adalah fungsi dari Panjang gelombang $(\lambda)$ dan panjang kapal (L).
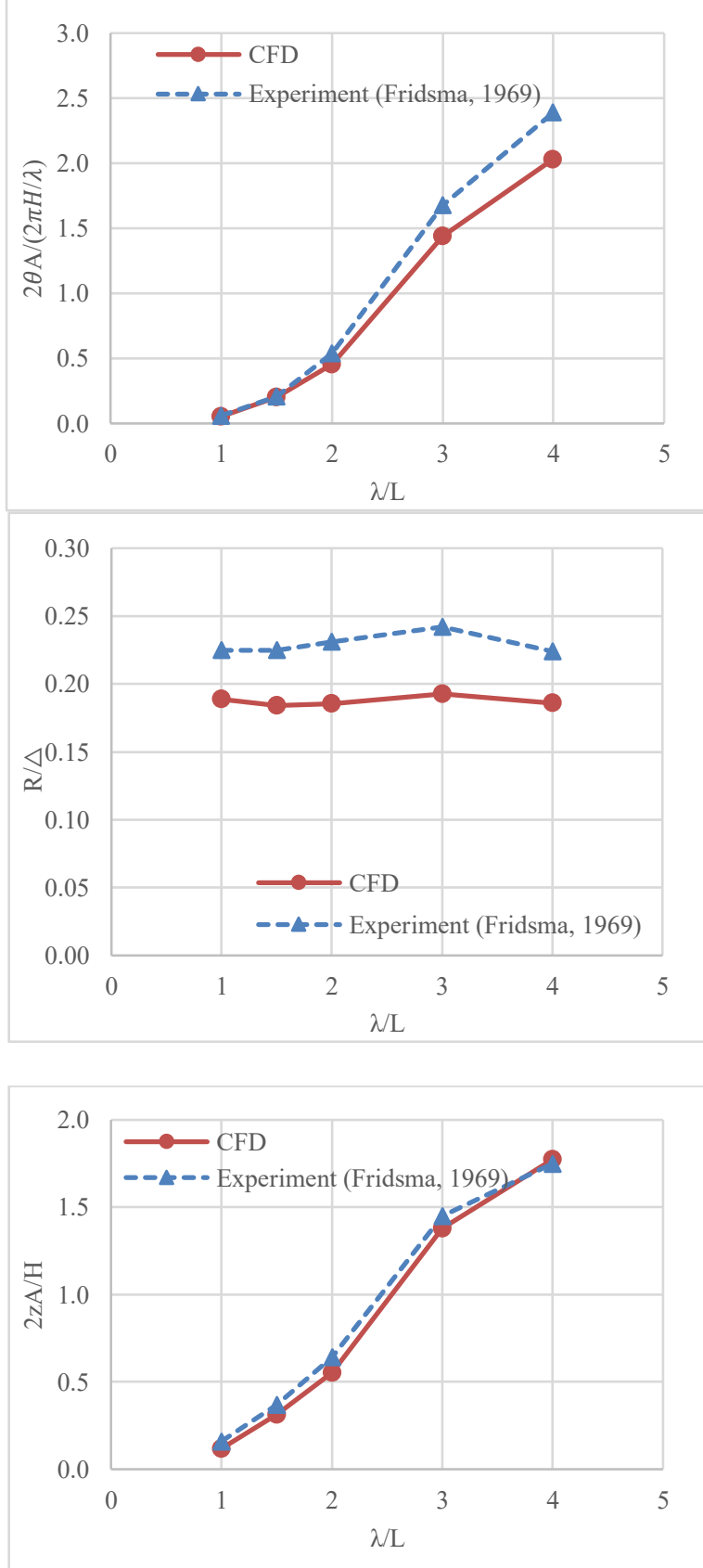

Gambar 8. Perbandingan CFD dan eksperimen Fridsma-B pada kondisi tinggi gelombang 0,025 $\mathrm{m}$ dan $\mathrm{Fr}=1.78$.

Gambar 9 dan gambar 10 menunjukan perbandingan CFD dan eksperimen pada kondisi tinggi gelombang $0.025 \mathrm{~m}$ dan $\mathrm{Fr}=0.59$. Fridsma 
C dan D memiliki sedikit perbedaan pada letak Longitudinal Center of Gravity (LCG) dan pitch gyradius (k) yang berkaitan dengan fungsi moment inersia kapal. Pada percobaan mengunakan model ini, hampir semua aspek memiliki persamaan antara hambatan total, pitch dan heave.
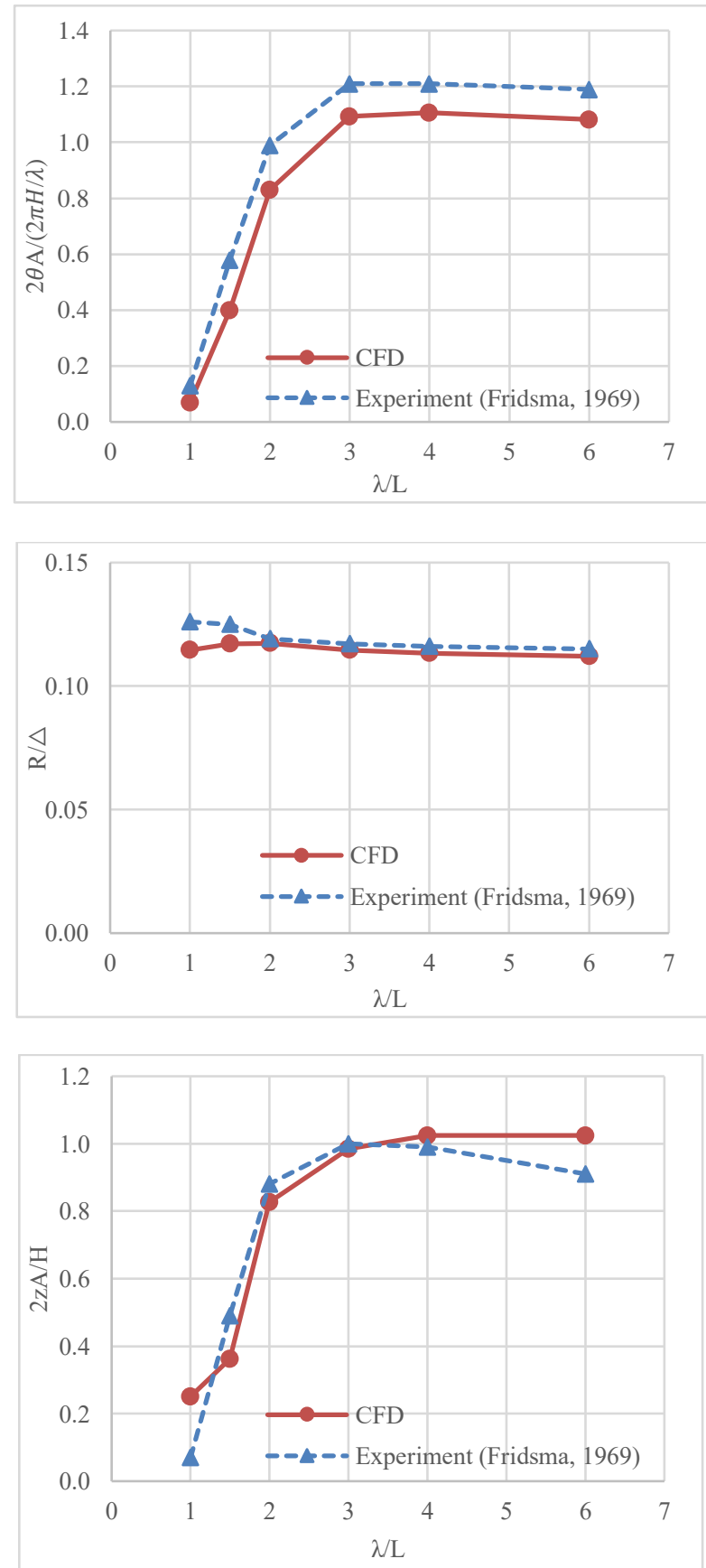

Gambar 8. Perbandingan CFD dan eksperimen Fridsma-C pada kondisi tinggi gelombang 0.025 $\mathrm{m}$ dan $\mathrm{Fr}=0.59$
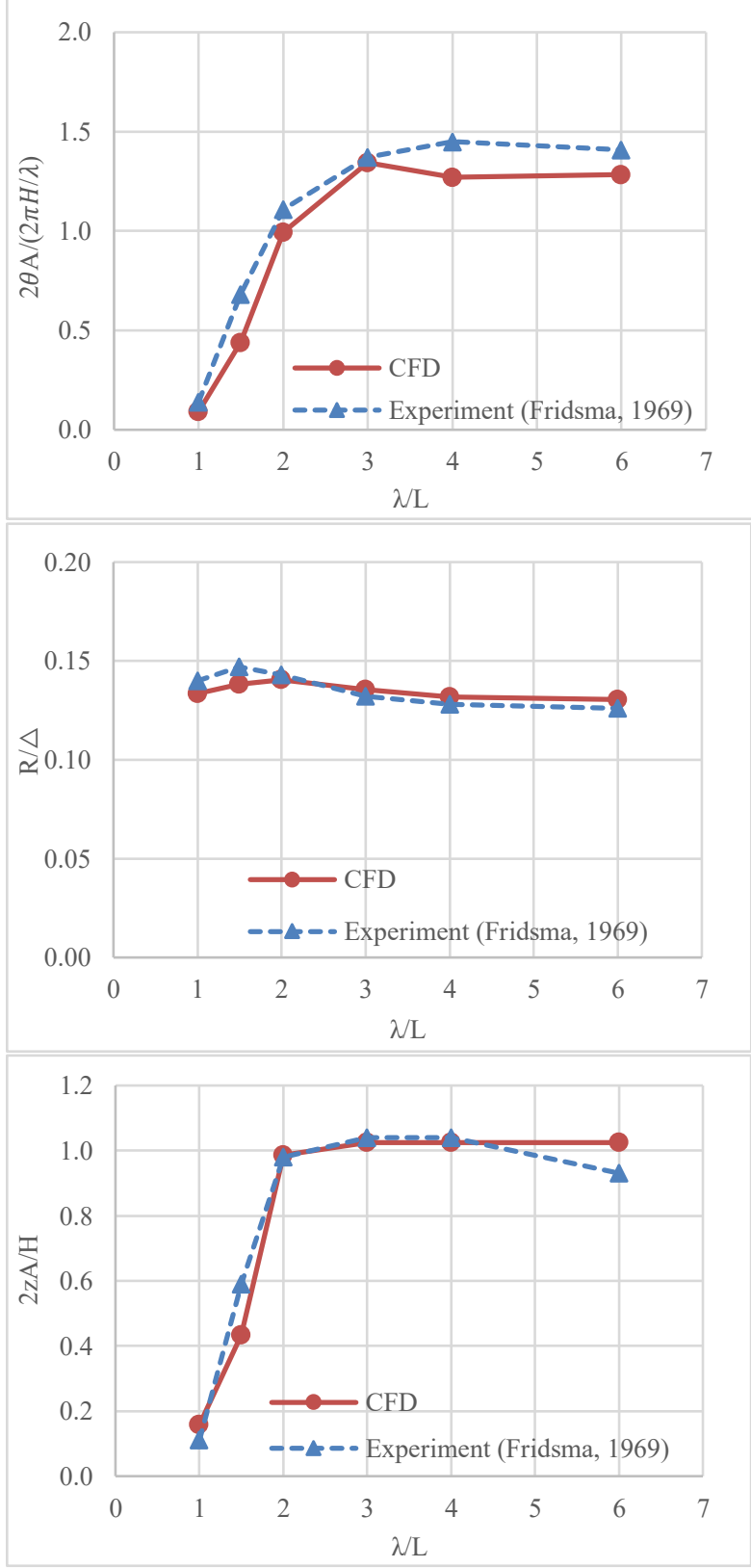

Gambar 8. Perbandingan CFD dan eksperimen Fridsma-D pada kondisi tinggi gelombang 0.025 $\mathrm{m}$ dan $\mathrm{Fr}=0.59$

\section{KESIMPULAN}

CFD merupakan salah satu metode yang paling sering digunakan untuk memecahkan persamaan dinamika fluida yang cukup akurat. Pemodelan yang kompleks dapat diselesaikan menggunakan simulasi komputasi yang modern tanpa mengurangi hasil akhir.

Pada simulasi CFD di air tenang menunjukan hasil yang akurat sesuai dengan hasil uji eksperimen.

Sementara, berdasarkan hasil simulasi numerik, ada indikasi bahwa pada kecepatan kapal yang tinggi $(\mathrm{Fr}=1.78)$ ada ketidakmampuan perhitungan numerik yang harus dievaluasi. Sementara untuk kecepatan kapal $\mathrm{Fr}=$ 
0.59, CFD mampu memberikan hasil yang akurat, sesuai dengan hasil eksperimen.

\section{UCAPAN TERIMA KASIH}

Penulis mengucapan terima kasih kepada Laboraturium Ship Design, Department Naval Architecture and System Engineering di Pukyong National University atas dukungan dalam melakukan penelitian ini.

\section{DAFTAR PUSTAKA}

[1] G. Fridsma, "A Systematic study of the rough-water performance of planing boats," Hoboken, New Jersey, 1969.

[2] G. Fridsma, "A Systematic study of the rough-water performance of planing boats. Irregular waves.," Hoboken, New Jersey, 1971.

[3] D. Savitsky, "Hydrodynamic design of planing hulls," Mar. Technol. SNAME, vol. 1, no. 1, pp. 71-95, 1964.

[4] R. Yousefi, R. Shafaghat, and M. Shakeri, "Hydrodynamic analysis techniques for high-speed planing hulls," Appl. Ocean Res., vol. 42, pp. 105-113, 2013.

[5] R. Yousefi, R. Shafaghat, and M. Shakeri, "High-speed planing hull drag reduction using tunnels," Ocean Eng., vol. 84, pp. 54-60, 2014.

[6] V. Subramanian, "Pressure and drag influences due to tunnels in high-speed planing craft," Int. Shipbuild. Prog., vol. 54, pp. 25-44, 2007.

[7] P. Lotfi, M. Ashrafizaadeh, and R. K. Esfahan, "Numerical investigation of a stepped planing hull in calm water," Ocean Eng., vol. 94, pp. 103-110, 2015.

[8] S. M. Mousaviraad, Z. Wang, and F. Stern, "URANS studies of hydrodynamic performance and slamming loads on highspeed planing hulls in calm water and waves for deep and shallow conditions," Appl. Ocean Res., vol. 51, pp. 222-240, 2015.

[9] M. Caponnetto, "Practical CFD simulations for planing hulls," Int. Conf. High Perform. Mar. Veh. (HIPER' 01), no. May, 2001.

[10] M. Caponnetto, H. Söding, and R. Azcueta, "Motion simulations for planing boats in waves," Sh. Technol. Res., vol. 50, no. 4, pp. 182-198, 2003.

[11] I. Akkerman, J. Dunaway, J. Kvandal, J. Spinks, and Y. Bazilevs, "Toward freesurface modeling of planing vessels:
Simulation of the Fridsma hull using ALEVMS," Comput. Mech., vol. 50, no. 6, pp. 719-727, 2012.

[12] S. Brizzolara and F. Serra, "Accuracy of CFD codes in the prediction of planing surfaces hydrodynamic characteristics," 2nd Int. Conf. Mar. Res. Transp., no. June 2007, pp. 147-158, 2007.

[13] A. De Marco, S. Mancini, S. Miranda, R. Scognamiglio, and L. Vitiello, "Experimental and numerical hydrodynamic analysis of a stepped planing hull," Appl. Ocean Res., vol. 64, pp. 135-154, 2017.

[14] A. G. Avci and B. Barlas, "An experimental and numerical study of a high-speed planing craft with full-scale validation," J. Mar. Sci. Technol., vol. 26, no. 5, pp. 617-628, 2018.

[15] B. Launder and D. Spalding, "The numerical computation of turbulent flows," Comput. Methods Appl. Mech. Eng., vol. 3, pp. 269-289, 1974.

[16] ITTC, "Practical guidelines for ship CFD applications," in Specialist Committee on CFD in Marine Hydrodynamics of the 27th ITTC, 2014.

[17] A. Federici, "Design and analysis of nonconventional hybrid high-speed hulls with hydrofoils by CFD methods," University of Genoa, 2014. 